\title{
Türkiye ve Güney Kıbrıs Rum Yönetimi’nin Doğu Akdeniz Enerji Politikalarının Neorealist Perspektiften Karşılaştırmalı Analizi*
}

\section{A comparative Analysis of the Eastern Mediterranean Energy Policies of Turkey and the Greek Cypriot Administration of Southern Cyprus from a Neorealist Perspective}

\author{
Muhammed Fatih iMAMOĞLU1 ${ }^{1}$, Ayşe Gülce UYGUN²
}

\section{$\ddot{O}_{z}$}

Doğu Akdeniz; farklı din, mezhep, siyasi ve etnik grupları bünyesinde barındıran bir bölge olup tarih boyu çatısmalara sahne olmuștur. Kıyıdaş devletlerin güvenliğini tehdit eden bu çatışmalar devam ederken, bölgede hidrokarbon kaynaklarının keşfedilmesi, gerilimi ve rekabeti besleyici bir etki yaratmaktadır. Günümüzde diğer tüm işlevlerinin yanı sıra aktörler tarafından rakiplerine karşı bir baskı aracı olarak da kullanılan enerji, bir güç unsuru olarak karşımıza çıkmaktadır. Enerjinin devletlerin güvenlik açıklarını azaltıcı bir etkisinin olması, bu kaynaklar üzerinde hakimiyet kurma mücadelesini doğurmaktadır. Türkiye, artan enerji ihtiyacını karșılamak ve enerji geçiş merkezi olma hedefini sürdürmek için bölgeye olan ilgisini artırmaktadır. Güney Kıbrıs Rum Yönetimi ise, güvenlik açıklarını azaltma ve kaynakların büyük bir bölümünü ihraç ederek ekonomik kazanç elde etme gayreti içerisindedir. Bu çalışmada, Türkiye ve Güney Kıbrıs Rum Yönetimi’nin enerji politikaları kapsamında çatışan çıkarları değerlendirilmektedir. İki aktörün Doğu Akdeniz enerji politikaları neorealist perspektiften ele alınarak ulusal çıkar, güc, çatışma, rekabet, güc dengesi ve güvenlik kavramları çerçevesinde karşılaştırmalı bir analiz yapılmaktadır.

Anahtar Kelimeler : Doğu Akdeniz, Türkiye, Güney Kıbrıs Rum Yönetimi, Neorealizm, Enerji

\begin{abstract}
The Eastern Mediterranean constitutes a region that includes different religious, sectarian, political and ethnic groups and has been home to conflicts throughout the history. While these conflicts that threaten the security of the riparian states continue, the discovery of large hydrocarbon resources in the region has created a nurturing effect on tension and competition between actors. Today, energy, along with its other functions, is used by actors as a means of pressure against their rivals, thus constitutes a component of power. The fact that energy has a reducing effect on the security vulnerabilities of states, causes the struggle for dominance over these resources. Turkey has shown a growing interest in the region to meet its increasing energy needs and to maintain its goal of becoming an energy transition center. The Greek Cypriot Administration, on the other hand, has been in an effort to reduce security gaps and maximize economic gain by exporting a large part of its resources. In this study, the conflicting interests of Turkey and the Greek Cypriot Administration within the scope of their energy policies are evaluated through the rational dynamics of the International Relations discipline. The Eastern Mediterranean energy policies of the two actors are examined from a neorealist perspective, and a comparative analysis is made within the framework of the concepts of national interest, power, conflict, competition, balance of power and security.
\end{abstract}

Keywords: Eastern Mediterranean, Turkey, Greek Cypriot Administration, Neorealism, Energy

\footnotetext{
${ }^{*}$ In this article, the principles of scientific research and publication ethics were followed. / Bu makalede bilimsel araştırma ve yayın etiği ilkelerine uyulmuştur. "Bu çalışma, birinci yazarın ikinci yazar danışmanlığında tamamlanan “Türkiye ve Güney Kıbrıs Rum Yönetimi'nin Doğu Akdeniz Enerji Politikalarının Neorealist Perspektiften Karşılaşıırmalı Analizi: Kıbrıs Ekseninde Çatışma Alanları" başıılı yüksek lisans tezinden üretilmiştir.

"This study has been produced from the Master's thesis titled "A Comparative Analysis of the Eastern Mediterranean Energy Policies of Turkey and the Greek Cypriot Administration of Southern Cyprus from a Neorealist Perspective: Conflict Areas on the Cyprus Axis", completed by the first author under the supervision of the second author.
}

\section{${ }^{1}$ Muhammed Fatih iMAMOĞLU}

ORCID ID: 0000-0003-0229-8712

Yüksek Lisans, Çanakkale Onsekiz Mart Üniversitesi, Lisansüstü Eğitim Enstitüsü, Uluslararası İlişkiler Anabilim Dalı, mf.imamoglu@hotmail.com

MSc., Çanakkale Onsekiz Mart University, School of Graduate Studies, Department of International Relations, mf.imamoglu@hotmail.com

\section{${ }^{2}$ Ayşe Gülce UYGUN}

ORCID ID: 0000-0001-5072-2333

Dr. Öğr. Üyesi, Çanakkale Onsekiz Mart Üniversitesi, Siyasal Bilgiler Fakültesi, Uluslararası ilişkiler Bölümü, Çanakkale, Türkiye, gulceuygun@comu.edu.tr Asst. Prof. Dr., Çanakkale Onsekiz Mart University, Faculty of Political Sciences, Department of International Relations, Çanakkale, Türkiye, gulceuygun@comu.edu.tr

$\begin{array}{ll}\text { Geliş Tarihi/Received } & : 24.09 .2021 \\ \text { Kabul Tarihi/Accepted } & : 25.12 .2021 \\ \text { Çevrimiçi Yayın/Published } & : 25.12 .2021\end{array}$




\section{GiRiş}

Enerji, hayatın hemen her alanında ihtiyaç duyulan ve yaşamı sürdürebilmek için gerekli olan temel bir kaynaktır. Devletlerin askeri, ekonomik ve teknolojik gelişimi açısından oldukça önemli olan enerji kaynakları, günümüzde önemli bir üstünlük ve güç unsuru olarak görülmektedir (Cesnekas, 2010, 31; Zahid, 2008, 167). Özellikle petrol ve doğal gaz, yaşamı önemli ölçüde kolaylaştırmakla beraber devletlerin refahını arttırıcı etkiye sahiptir. Bu sebeple enerji arzında problemler yaşanması, devletler için hayati sorunlar doğurabilmektedir. Dolayısıyla devletler, enerji kaynaklarını en hesaplı, en güvenli ve kesintisiz yollarla tedarik etmek durumundadır. Bu bağlamda, aktörler söz konusu kaynaklara erişmek için birbirleriyle rekabet etmekten ve çatışmaktan kaçınmamakta ve bu yönüyle enerji, aktörlerin dış politik tutumlarını ve davranışlarını etkileyen unsurların içerisinde yer almaktadır.

Doğu Akdeniz bölgesinde son yıllarda keşfedilen enerji kaynakları, bölgesel ve küresel aktörlerin dikkatini çekmiş ve bölge, devletlerin egemenlik kurmak istediği önemli bir rekabet sahasına dönüşmüştür (Kavaz, 2020; Uygun, 2021; Yaycı, 2012,). İsrail, Kıbrıs Adası ve Mısır açıklarında keşfi gerçekleşen geniş enerji rezervleri, aktörlerin ilgisini bölgeye yöneltmiş ve özellikle kıyıdaş devletler arasında önemli bir enerji rekabeti doğmuştur. Enerji kaynaklarına olan ihtiyacın her geçen gün artması ve buna karşın kaynakların seyrekleşmesi dikkate alındığında Doğu Akdeniz kaynakları, bölgesel ve küresel aktörler için çıkarlarını maksimize ederek ekonomik ve siyasi kazanımlar sağlayabileceği önemli bir fırsat ve güç unsuru olarak görülmüştür. Ancak hem bölgesel hem küresel aktörlerin aynı amaç için bölgeye yönelmesi, çıkarların çatışmasına yol açmış ve ekonomik, siyasi ve hukuki vb. birçok farklı açıdan anlaşmazlıkları da beraberinde getirmiştir. Bu çerçevede bölge, önemli bir rekabet alanına dönüşmüş ve Doğu Akdeniz, sıcak çatışmaların yaşanma ihtimalinin yüksek olduğu bir coğrafya haline gelmiştir (Şahin, 2019, 23). Kıbrıs adası çevresindeki kaynaklar üzerindeki en yoğun anlaşmazlıklar, Türkiye ve Güney Kıbrıs Rum Yönetimi (GKRY) arasında yaşanmıştır ve iki aktörün özellikle kaynakların paylaşımı ve Avrupa topraklarına sevki konusundaki farklı tutumları, çatışma ve rekabeti beraberinde getirmiştir (Grigoriadis, 2014, 128). Bu sayede, Türkiye ve GKRY arasında kronikleşen sorunlara yenilerini eklemiş ve iki aktörün çatışan ulusal çıkarları, kaynaklar üzerindeki rekabeti körüklemiştir (Karakasis, 2014, 17).

Bu çatışma ve rekabet durumu sebebiyle iki aktörün enerji kaynaklarına yönelik politikalarının neorealist teori çerçevesinde değerlendirilebileceği düşüncesi doğmuştur. Dolayısıyla çalışmanın temel amacı, Kıbrıs çevresinde keşfedilen enerji kaynaklarına yönelik Türkiye ve GKRY'nin çatışmacı ve rekabetçi politikalarını analiz etmede neorelist kuramın ne derece etkin bir teorik çerçeve ortaya koyduğunu sorgulamaktır. Çalışmanın metodolojisi ise vaka çalışması (case study) olarak belirlenmiş, Doğu Akdeniz enerji kaynaklarına yönelik Türkiye ve GKRY'nin politikaları neorealist perspektiften ele alınarak karşılaştırmalı bir vaka çalışması gerçekleştirilmiştir. Bir diğer ifadeyle, Türkiye ile GKRY çalışmaya konu olan karşılaştırmalı analizin Doğu Akdeniz' deki iki vakasını teşkil etmekte, bu iki aktörün enerji kaynakları üzerindeki anlaşmazlıklarını, devletler arasındaki çatışmaları konu edinen neorealist teorinin görüşlerinden faydalanarak analiz etmek amaçlamaktadır. Özellikle, iki aktörün enerji politikaları, neorealist teorinin temel varsayım ve önermeleri olan ulusal çıkar, güç, çatışma, rekabet, güç dengesi ve güvenlik kavramları üzerinden karşılaştırılarak bir değerlendirme yapılmıştır. Bu bağlamda, çalışmanın giriş bölümünü oluşturan birinci bölümün ardından ikinci bölümünde neorealist kuram ele alınarak teorik çerçeve oluşturulmuştur. Üçüncü bölüm, Türkiye ve GKRY'nin Doğu Akdeniz enerji politikalarını açıklamak için ayrılmıştır. Dördüncü bölüm, iki aktörün politikalarının neorealist teori üzerinden değerlendirildiği bölüm olmuştur. Son olarak beşinci bölümde ise çalışmanın bulguları tartışılmıştır.

\section{TEORIK ÇERÇEVE: NEOREALIZM}

Neorealizm, realizmin küresel dünya düzenine yönelik savlarının gözden geçirilmesi ve güncellenmesi neticesinde ortaya çıkan bir teoridir. Realizme yönelik eleştirilere karşı teoriyi yeniden şekillendirme çabasına giren neorealistler, bu açıdan realist teoriyi günün şartlarına göre düzenleme intiyacı duymuşlardır. Böylelikle analizlerinde sistemin 'anarşik' yapısının altını çizen, devletlerin var olma mücadelesi verdiğini belirten ve bu yönüyle realist geleneğin bir parçası olan neorealizmin temelleri atılmaya başlanmıştır. Bu yeni teorinin önde gelen ismi Kenneth Waltz olmuştur. Kaleme aldığı "Uluslararası Politika Teorisi" (Theory of International Politics, 1979) eseriyle realist geleneği dönemin koşullarına uygun olarak yeniden şekillendirmeye çalışmıştır. Ancak bilinmelidir ki neorealizm, gerçekçi düşünceye bir tepki olarak doğan veya bütünüyle farklı bir tez üreten bir teori değildir.

Neorealist teori, esas olarak iki düşünce üzerine inşa edilmiştir. Birincisi, sistemi ve uluslararası yapıyı oluşturan temel aktör ve ana unsur ulus-devletlerdir ve hiyerarşik bir düzenin olmadığı bir yapıda devletler sağ kalmak için mücadele etmektedir (Ashley, 1984, 238). Sistemin bu 
yapısı, kural koyan bir üst merciinin olmadığı anlamına gelmektedir. İkinci olarak, kaosun hâkim olduğu sistemde devletlerin birincil ve en önemli hedefi, kendi güvenliğini sağlamak ve muhafaza etmektir (Mearsheimer, 2009, 242). Fakat her devlet, sahip olduğu olanaklar ve firsatlar açısından eşit değildir. Buna karşın hepsinin temel hedefi ve gayesi benzerdir (Waltz, 1979, 96). Dolayısıyla sistem, devletleri benzer politikalar izlemeye zorlamaktadır. Devletlerin benzer eylemlerde bulunması, sistemi analiz etmeyi kolaylaştırmaktadır. Waltz'a $(1979,72)$ göre uluslararası sistem, devletlerin politikalarını belirler, biçimlendirir ve yeri geldiğinde kısıtlar. Sistemin devletleri zorladığı ve mecbur bıraktığı davranış biçiminin başında güvenlik artırıcı politikalar gelir. Güvenlik açığını kapatmak isteyen devletler, rakipleri karşısında güçlü olmak için çabalar çünkü neorealizme göre güç, bir "amaçtan" ziyade var olabilmek için bir "araçtır" (Arı, 2004, 192-196). Bu yönüyle sistem, devletleri belirli yönde davranmaya zorlayarak devletlerin hareket kabiliyetini sınırlandırır.

Kenneth Waltz'un temsilciliğini yaptığı neorealist düşüncenin savları, kısaca beş maddede açıklanabilir. İlk olarak neorealizme göre uluslararası sistem, üst otoritenin olmadığı anarşik bir yapıdadır. Devletler böyle bir sistemde yalnızca kendilerine güvenmek durumunda ve çıkarları doğrultusunda güçlerini artırmak mecburiyetindedir. Ancak her devletin rakibine karşı güç elde etmek istemesi, bir rekabete yol açar. Bazı devletler daha çok güç elde ederken bazıları ise daha zayıf kalabilir. Bu sebeple güce olan gereksinim daima artar. Waltz'a göre, güce olan ihtiyacın sürekli artması, devletleri huzursuz edeceğinden devletlerin atması gereken en mantıklı adım sistemde dengeyi sağlamaktır. Diğer bir ifadeyle güçler dengesi adı altında ittifaklar gerçekleştirmektir (Waltz, 1979, 121). Dolayısıyla neorealistler açısından sistem her ne kadar anarşik olsa da bu durum her zaman çatışma sonucunu doğurmayabilir. Çünkü devletler sürekli güç için mücadele etmediğinden ya da sürekli bir savaş hali söz konusu olmadığından anarşik durum her zaman çatışmaya sebep olmaz. Bu açıdan neorealizm, devletlerin her zaman en kötü senaryoyu düşünerek o yönde hareket etmek zorunda olmadığını not eder. Ancak bir tehdit durumu söz konusu olduğunda devletler bu senaryoyu dikkate alır.

İinci olarak, uluslararası sahanın ana aktörü devletlerdir. Devlet var olma mücadelesi verir ve uluslararası sistemin esas ögesidir (Waltz, 1979, 93). Devletler dışındaki diğer küresel örgütlerin de sistem içerisinde önemli yeri vardır, ancak sistemin birincil unsuru devletlerdir. Devletlerin sahip olduğu askeri güç ve kapasite, bir tehdit unsuru olarak algılanabileceği için uluslararası yapı içerisinde ana aktör olarak kabul edilir. Bunun yanında neorealist düşünce sadece devleti değil, küresel örgütleri de analizlerine eklemesi yönüyle klasik/geleneksel realizmden ayrilır (Bayeh, 2014, 348).

Üçüncü olarak neorealizme göre devletler, rakibi olarak gördüğü devletlerin kendisi hakkında ne düşündüklerini bilemeyeceğini ve bir tahminde bulunamayacağını savunur. Bir devletin mevcut durumun değişimini arzu eden revizyonist ya da mevcut durumun devam etmesini arzu eden statükocu olup olmadığı bilinemeyeceğinden, neorealizm devletlerin daima şüpheci olması gerektiğine ve olaylara şüpheyle yaklaşması gerektiğine vurgu yapar (Gürsoy, 2005, 13).

Dördüncü olarak neorealizm, devletlerin zaman zaman farklı politikalara yöneldiğini ifade etse de asıl amacın sağ kalmak ve var olma mücadelesi vermek olduğunu belirtir. Devletler kimi zaman iktisadi, sosyal ve kültürel alanlara ağırlık verse de son tahlilde bağımsızık, egemenlik ve toprak bütünlüğünü muhafaza etmek her devletin öncelikli hedefidir.

Son olarak neorealizme göre, devlet akılcı ve rasyonel bir varlıktır. Çünkü devlet her zaman akıl ve bilim ile hareket eder, kar-zarar hesabı üzerinden politikalarını belirler. Kısacası devletler, sağ kalabilmek için her şeyi düşünmek ve ona göre hareket etmek zorundadır. Ancak bu durum, devletlerin kusursuz olduğu anlamına gelmez. Çünkü devletler de doğru ve kesin bilgiye tamamen hâkim olamaz ve hatalı eylemlerde bulunabilir (Dunne, Kurki \& Smith 2013, 79).

Öte yandan, neorealist teori, güç kavramını iki farklı şekilde ele almaktadır. Bir 'araç' olarak düşünüldüğünde, devletler var olabilmek, hayatta kalabilmek ve güvenliklerini sağlamak için güce ihtiyaç duyarlar. Bu görüşü benimseyen kuram Savunmacı Realizm adını almıştır (Mastanduno, 1997, 79, Waltz 2008, 79). Savunmacı realist kurama göre, bir aktörün gücü, coğrafi yakınlık, uluslararası ekonomik baskıcı tutumlar, tehtit algısı, karşılıklı askeri dengeleme ihtiyacı, stratejik doğal kaynaklara erişim gibi yapısal faktörler ekseninde arttırabilir (Rose, 1998). Güce ulaşmanın devletlerin asıl 'amacı' olduğunu savunanlara göre ise güç, aktörlerin izlediği politikalar ile elde etmek istediği bir sonuçtur ve literatürde Saldırgan Realizm adı verilmiştir. Savunmacı realizm ile saldırgan realizm, güç kavramına yapmış olduğu 'araç' ve 'amaç' olarak farklılaşan yaklaşım ile ayrışmaktadır (Pashakhanlou, 2018, 1).

Neorelist kurama göre, aktörler için ulusal güvenlik her ne kadar çoğunlukla askeri bir anlam ifade etse de, özellikle son dönemde güvenliğin tanımı salt askeri tehditlerle sınırlandırılamayacak kadar genişlemiş durumdadır (Kökyay, 2020). Bu bağlamda, mevcut çalışmada analiz edilen iki aktörün enerji politikaları, Doğu Akdeniz'de güvenlik kaygıları ile doğrudan ilgili görülen ekonomik ve siyasi çıkar 
çatışmaları, ekonomik güvenlik ve enerji güvenliği gibi kavramlar ekseninde ele alınmaktadır.

\section{TÜRKIYE VE GKRY’NIN DOĞU AKDENIZ'E YÖNELIK ENERJI POLITIKALARI}

Doğu Akdeniz'in enerji üretim merkezi statüsü kazanması, 21. yüzyılın başında gerçekleşen hidrokarbon keşiflerine dayanır. Daha önce de çalışmalar yapılmasına rağmen bu keşifler, teknolojik gelişmelere paralel olarak 2000'li yıllarda yoğunlaşmıştır. Keşfedilen doğal gaz ve petrol kaynakları Doğu Akdeniz'in stratejik önemini artırmış, bölgesel ve küresel aktörlerin ilgisinin bölgeye yönelmesini sağlamıştır. ilk keşiflerin ardından bölgede yoğun çalışmalara başlayan küresel enerji şirketleri, 2003 yılında Mısır açıklarında bulunan Nil sahasında geniş enerji kaynaklarının varlığını tespit etmiştir. Hollanda menşeili Shell firmasının bu keşfi, İsrail başta olmak üzere diğer bölge ülkelerinin enerji arama faaliyetlerini hızlandırmıştır. $\mathrm{Bu}$ çerçevede günümüze dek çok yoğun araştırmalar yapılmıs ve bu coğrafyada değeri milyar dolarları bulacak ölçüde kaynağın varlığı tespit edilmiştir (İstikbal \& Boyraz, 2019, 72).

Doğu Akdeniz coğrafyasında potansiyel enerji kaynaklarına yönelik en geniş ve kapsamlı rapor 2010 yılında Amerika Birleşik Devletleri (ABD) Jeoloji Araştırma Kurumu'nun yaptığı çalışma olmuştur (USGS, 2010). Söz konusu rapor, yayınlandığı tarih itibariyle, Mısır açıklarında bulunan Nil sahasında yaklaşık 1,8 milyar varillik bir petrolün, 6,3 trilyon metreküplük doğalgazın ve 6 milyar varillik sıvı doğal gazın (LNG) varlığından söz etmektedir. İsrail, Filistin, Lübnan ve Kıbrıs adasının güneyini içine alan Levant Havzası'nda ise, yaklaşık olarak 3,45 trilyon metreküplük doğal gaz ve 1,7 milyar varil petrolün varlığı tespit edilmiştir. Rapora göre, sadece Levant ve Nil havzasının enerji kaynağı kapasitesi yaklaşık 10 trilyon metreküp doğal gaza ve 3,5 milyar varil petrole denk gelmektedir. Ayrıca rapor, Kıbrıs ve çevresinde değeri yaklaşık 400 milyar doları bulan 8 milyar varil petrolün varlığından söz etmektedir (USGS, 2010).

Bölge şartlarına bakıldığında Kıbrıs ve İsrail gibi az nüfuslu aktörlerin bulunması ve iklimin sıcak olması, diğer ülkelere oranla bu aktörlerin doğal gaz talebinin nispeten az olduğunu göstermektedir. Dolayısıyla keşfedilen kaynakların tamamına yakını başta Avrupa olmak üzere farklı noktalara ihraç edilebilir niteliktedir.

Doğu Akdeniz'deki enerji kaynakların keşfi, bölgeyi enerji üretim potansiyeline sahip önemli bir merkeze dönüştürmüş ve bölgesel aktörlerin yanında küresel aktörlerin de dikkatini çekmiştir. Dolayısıyla Avrupa Birliği (AB) (Uygun, 2021), ABD (Karagiannis, 2016, Özekin, 2020),
Rusya (Ametbek, 2019, Delanoe, 2013) ve Çin (Örselli \& Babahanoğlu, 2019; Pekcan \& Uygun, 2021) gibi küresel aktörler de Doğu Akdeniz'e yönelerek bölgedeki enerji denkleminde yer almışlardır. Kıyıdaş aktörlerin yanı sıra, küresel aktörlerin de bölgeye artan ilgisi, Doğu Akdeniz'deki rekabeti besleyici bir etki yaratmış, güç dengesi ve çıkar çatışmalarına farklı boyutlar kazandırmış ve Türkiye ve GKRY'nin bölgeye yönelik tutumlarında da etkili olmuştur.

\subsection{Türkiye'nin Doğu Akdeniz Enerji Politikası}

Türkiye petrol ve doğal gaz gibi stratejik kaynaklar bakımından zengin ülkelere yakın bir coğrafyadadır. Türkiye'nin sahip olduğu bu konum, onu petrol ve doğal gaz akışı noktasında bir transit ülke haline getirerek bölgede sözü geçen bir oyuncu yapmıştır (Yazar, 2011, 64). Dolayısıyla Türkiye, hem kendi enerji arz güvenliğini sağlama konusunda hem de bu zengin kaynakları Avrupa'ya aktarma konusunda bugüne dek coğrafi konumunun sunduğu fırsatlardan yararlanmak istemiştir (Karagöl vd., 2016, 10). Ancak Türkiye'nin artan nüfusu ve gelişen ekonomisi, enerjiye olan ihtiyacını arttırmıştır. Bu durum, Türkiye'nin enerji konusunda dışa bağımlılığının artmasına sebep olmuştur. Öyle ki, 2018 yılı itibariyle Türkiye'nin enerji kaynaklarında dışa bağımlılık oranı $\% 72,4$ düzeylerinde seyretmiştir (TPAO, 2019, 32). Dolayısıyla Türkiye, enerjideki artan maliyetini minimize etmek için dış kaynaklara olan bağımlılığını azaltmak durumunda kalmış ve yakın çevresinde keşfedilen yeni zenginlikleri verimli bir şekilde kullanma ihtiyacı hissetmiştir. Bu açıdan Doğu Akdeniz havzasında son yıllarda keşfi gerçekleşen kaynaklar, Türkiye'nin enerji ithalatını düşürme potansiyeline sahiptir (Kedikli \& Deniz, 2015, 413). Bu doğrultuda Türkiye, son yılların gündemini yoğun bir şekilde meşgul eden Doğu Akdeniz coğrafyasına yönelerek bölgenin sıcak gündemiyle yakından ilgilenmiş, buradaki çalışmalarına hız vermiştir.

Elbette Türkiye'nin bölgeye artan ilgisinin tek sebebi enerji kaynaklarına erişim değildir. Tarihsel süreçte, Türkiye'nin Doğu Akdeniz yaklaşımının en önemli belirleyicilerinin başında Kıbrıs sorunu gelmiştir. Türkiye'nin son dönem Doğu Akdeniz enerji politikasında yine Kıbrıs sorunu belirleyici olmuş, politikalar Yunanistan ve GKRY'nin kaynaklara yönelik hamleleri göz önünde bulundurularak şekillenmiştir (Boyraz \& Balcı, 2021). Özellikle GKRY'nin Türkiye'yi ve Kuzey Kıbrıs Türk Cumhuriyeti (KKTC)'yi yok sayan kışkırtıcı politikaları, Türkiye'nin bölgede daha agresif bir tutum sergilemesine sebep olmuştuştur. GKRY'nin enerji kaynaklarına yönelik küresel enerji şirketlerine arama ruhsatı vererek sürdürdüğü politikalar, Türkiye ve KKTC tarafından yoğun tepkilerle karşılanmış ve Türkiye tutumunu sertleştirmiştir (Özekin, 2020, 32). Kıbrıs Cumhuriyeti'nin kuruluşunu hazırlayan anlaşmaya göre 
KKTC'nin garantörlüğünü elinde bulunduran Türkiye, GKRY'nin yürüttüğü politikalara karşı KKTC'nin hak ve menfaatlerinin çiğnenmesine izin verilmeyeceğini her fırsatta dile getirmiştir. Ayrıca Türkiye, kaynaklara erişimi egemenlik ve uluslararası hukuktan doğan bir hak olarak görmüştür. Kıbrıs adası üzerinden düşünüldüğünde, Türkiye'nin bu tutumu bir haktan ziyade yükümlülük olarak da görülmüştür (Sandıklı vd., 2012, 2). Bu sebeple Türkiye hem kendi hem de Kıbrıslı Türklerin hak ve menfaatlerini yok sayma niyetinde olan GKRY ve Yunanistan'ın politikalarına sert şekilde tepki göstermiştir.

Türkiye'nin Doğu Akdeniz enerji kaynaklarına yönelik politikası 2010'lu yıllardan itibaren giderak artan bir seyirde yoğunlaşmıştır. Bu bağlamda Türkiye'nin ilk adımı envanterine sismik araştırma ve sondaj gemileri katmak olmuştur. Bu yönde atılan adımlar neticesinde Türkiye, ilk olarak 2012 yılında Barbaros Hayrettin Paşa sismik araştırma gemisinini satın almıştır. Sonraki süreçte ise toplamda 2 tane sismik araştırma gemisi, 3 tane de sondaj gemisi, Türk envanterine dâhil edilmiştir (Temizer, 2020). Türkiye, bu gemiler sayesinde denizlerdeki gücünü artırmanın yanı sıra faaliyetlerini bağımsız bir şekilde yürütebilme kapasitesine erişme gayesi taşımıştır.

Türkiye'nin yakın dönem Doğu Akdeniz stratejisinde öne çıkan hamleleri ve oyun değiştirici olma niyeti taşıyan diplomatik girişimleri olmuştur. Illk olarak, Doğu Akdeniz havzasında enerji kaynaklarının varlığının ispatının ardından GKRY'nin tek taraflı olarak Kıbrıs Cumhuriyeti adına kıyıdaş devletlerle anlaşmalar yapmasını eleştirmiş ve diplomatik kanallarla tepki göstermiştir. Bu süreçte GKRY, ilk olarak 2003'te Mısır ile 2007'de Lübnan ile 2010 'da ise İsrail ile anlaşmalar yapmıştır (Acer, 2020, 15). Ancak Türkiye, bu anlaşmalar ile KKTC'nin hak ve menfaatlerinin görmezden gelindiği gerekçesi ile anlaşmaları Kıbrıs sorununa zarar verici bir adım olarak değerlendirmiştir. Ayrıca Türkiye, bölgede barış adımlarına ve istikrara zarar verecek nitelikte gördüğü anlaşmaları tanımadığını Birleşmiş Milletler (BM)'ye bildirmiştir (Dışişleri Bakanlığı, 2010).

İkinci olarak Türkiye, GKRY'nin 2007 yılında adanın güneyini 13 parsele bölerek içerisinde Türkiye ve KKTC sahalarının da olduğu alanlarda küresel enerji şirketlerine ruhsat vermek suretiyle arama-sondaj çalışmalarını başlatmasına hem masada hem sahada tepki göstererek karşılık vermiştir. GKRY'nin bu şekilde tek taraflı bir adım atma hakkının bulunmadığını belirten Türkiye, bu durumun uluslararası hukuka aykırı olduğunu ifade etmiştir (Karagül, 2021, 63). Aşağıda yer alan Şekil'de GKRY tarafından belirlenen 13 parsel ve KKTC ile Türkiye'nin hak iddia ettiği alanların çakıştığı görülmektedir. Şekildeki 1, 4, 5, 6 numaralı parsellerin kendi deniz yetki alanlarına girdiğini belirten Türkiye, 2, 3, 8, 9, 12, 13 numaralı alanlarda ise Kıbrıs Türk kesiminin de hakkı olduğunun altını çizmiştir (Peker vd., 2019: 93).

Üçüncü olarak, GKRY'nin farklı enerji şirketlerine ruhsat vermesine karşılık Türkiye, 21 Eylül 2011 yılında KKTC ile "Kıta Sahanlığını Sınırlama Anlaşması" imzalamış ve bu anlaşma ile KKTC, Türkiye Petrolleri Anonim Ortaklığı (TPAO)'ya arama faaliyetleri yapması için yetki vermiştir (Kısacık \& Erenel, 2019, 59). KKTC'nin verdiği ruhsatlar ile sondaj faaliyetlerini yütüren Türkiye için hukuki dayanak oluşmuştur. Ancak, KKTC'nin egemen bir aktör olarak kabul görmemesi ve sadece Türkiye tarafından tanınması uluslararası hukuk zemininde bölgesel aktörler nezdinde kullanılan bir argüman olmuştur. Bu noktada satın alınan gemilerle beraber sismik arama faaliyetlerine yoğunlaşan Türkiye açısından Doğu Akdeniz konusu, 2010'lar itibari ile, ekonomik kazanç elde etmenin ötesinde hak ve çıkarlarını koruma mücadelesi niteliği kazanmıştır.

Şekil 1: Kıbrıs Çevresinde İhtilafıı Deniz Alanları

Kıbrıs çevresindeki ihtilaflı deniz alanları

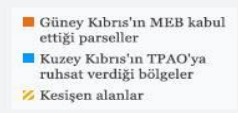

\% Kesisen alanlar

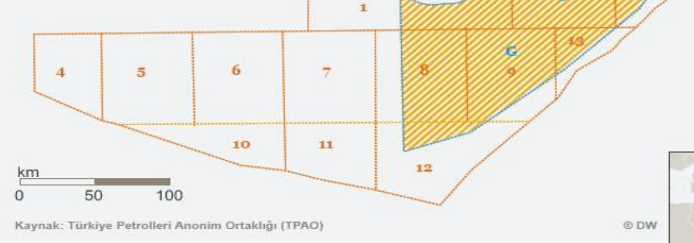

Kaynak: Deutsche Welle, (2021).

Dördüncü olarak, Türkiye'nin Doğu Akdeniz coğrafyasında atmış olduğu bir önemli bir adım Libya ile 2019 yılının Kasım ayında imzalanan Akdeniz'de Deniz Yetki Alanlarının Sınırlandırılmasına illişkin Mutabakat olmuştur (Resmî Gazete, 2019). Söz konusu mutabakatın 4.maddesi gereği iki ülke sınırlarının kesiştiği bir noktada enerji kaynağına rastlanması durumunda, bu kaynakların üretimi ve işlenmesi hususunda ortak çalışma yürütülecektir. Aynı maddenin devamında ise iki ülkenin üçüncü bir ülke ile benzer nitelikte diyalog haline girmesi durumunda karşılıklı olarak bilgilendirme yapılacağı üzerinde fikir birliğine varılmıştır (Acer, 2019, 12).

Türkiye'nin Libya hamlesinin ardından Akdeniz'in doğusunda diplomatik girişimler yoğunlaşmış ve Yunanistan başta olmak üzere diğer kıyıdaş aktörler Türkiye ve Libya'yı sert bir dille eleştirmiştir. Özellikle Yunanistan, bu mutabakatın uluslararası hukuka uygun olmadığını ifade ederek Libya adına anlaşmayı imzalayan hükümetin bu anlaşmayı imzalama yetkisinin bulunmadığını belirtmiştir. 
Bu tepkilere ilave olarak Yunanistan, Libya'nın Atina Büyükelçisini ülkede "istenmeyen kişi" (Persona Non Grata) olarak duyurmuş ve üç gün içerisinde ülkeden ayrılmasını istemiştir (TRT Haber, 2019). Ancak Türkiye açısından, Yunanistan'ın iddia ettiği gibi Libya hükümetinin bu anlaşmayı imzalamaya ehil olmadığı gibi bir durum söz konusu değildir. Zira anlaşmaya onay veren hükümet, BM'nin Libya adına tanımış olduğu meşru yönetimdir. Dolayısıyla uluslararası hukuk açısından bu mutabakat geçerli olmakla birlikte Yunanistan'ın ortaya attığı iddialar Türkiye tarafından geçersiz kabul edilmiştir (Caşın, 2019). Yunanistan, Türkiye'nin Libya hamlesine bir karşı hamle olarak 2020 yılının Ağustos ayında Mısır ile bir anlaşma imzalamış ve Libya mutabakatını reddettiğini yinelemiştir. Ayrıca bu anlaşma, Mısır'ın da Libya mutabakatına karşı çıktığının bir göstergesi olmuştur. Bu restleşmeler, tarafların geri adım atmama konusunda kararlı duruşunu göstermekte ve ileride yeni gerginliklerin ortaya çıkmasına sebep olabilecek ve tansiyonu artıracak niteliktedir.

Son olarak Türkiye, bölgede tüm siyasi ve diplomatik haklarını hem masada hem sahada kullanma konusundaki tutumunu askeri önlemleri devreye sokarak desteklemiştir. Özellikle arama faaliyetleri yürüten gemilerin güvenliğini sağlama noktasında hava ve deniz gücünü bölgeye yönlendirmiş ve günümüze dek büyük çaplı tatbikatlar düzenlemiştir (Reuters, 2020). Bir gövde gösterisi niteliğinde olan bu tatbikatlar, Türkiye'nin caydırıcı bir askeri kapasiteye sahip olduğunu gösterme hedefi taşımıştır. Türkiye'nin denizlere yönelik bu motivasyonu, denizlerin savunmasına yönelik olarak ileri sürülen ve son dönemde sıkça vurgu yapılan Mavi Vatan kavramı ile açıklanmıştır. Mavi Vatan kavramına göre, bir ülkenin vatanı sadece kara toprakları değildir. Karasal alanlara ek olarak hava ve deniz sahaları da bir ülkenin vatanını oluşturur. Denize kıyısı bulunan devletlerin sahip olduğu karasuları, kıta sahanlıkları ve Münhasır Ekonomik Bölge (MEB) alanları da ülkelerin vatanını oluşturan unsurlardır. Bu düşünceden yola çıkarak Mavi Vatan kavramsallaştırması, Türkiye'nin denizlerdeki haklarını, çıkarlarını ve güvenliğini koruması ve toplumun bu noktada bilinçlendirilmesi bakımından oldukça önemlidir (Ak, 2013, 334).

Türkiye'nin tarihsel süreçte Doğu Akdeniz politikasının belirleyicisi olan Kıbrıs sorunu, hidrokarbon keşiflerinin ön plana çıktığı 2010'lu yıllardan itibaren yine belirleyici olmaya devam etmiştir. Kronikleşen siyasi çekişmelere ve güvenlik endişelerine, son dönemde bir de deniz yetki alanları sınırlandırma tartışmaları, bölgesel ve bölge dışı aktörlerin tutumları ve enerji güvenliği gündemi de eklenmiştir.

\subsection{GKRY'nin Doğu Akdeniz Enerji Politikası}

Doğu Akdeniz coğrafyasının en büyük adası konumunda olan Kıbrıs, geçmişten günümüze stratejik bir öneme sahiptir. Ada, bünyesinde iki farklı milleti barındırmakta, güneyi GKRY, kuzeyi ise KKTC tarafından yönetilmektedir. Dolayısıyla adanın yakın çevresinde keşfi gerçekleşen hidrokarbon kaynakları üzerinde her iki milletin de hukuki açıdan hak ve çıkarı bulunmaktadır. Buna rağmen Türk kesimini yok sayan ve görmezden gelen GKRY, adanın tek egemen temsilcisi iddiası ile hareket etmektedir (Yıldız, 2008, 89).

GKRY, Doğu Akdeniz kaynaklarından büyük oranda kazanç elde etmek ve faydalanmak için etkili olabilecek adımlar atmaktadır. Bu minvalde GKRY'nin ilk adımı, 1979 tarihine dayanmaktadır. Mısır ile ortak hareket ederek Doğu Akdeniz açıklarında hidrokarbon arama çalışmalarına başlayan GKRY, KKTC'nin bu adımı bir savaş sebebi (Casus Belli) olarak nitelendirmesi üzerine faaliyetlerini durdurmuştur (Orhun, 2017, 41). 2003 yılına kadar bu süreci donduran GKRY, bu tarihten itibaren Doğu Akdeniz açıklarında birtakım keşiflerin gerçekleşmesi üzerine yeniden aktif bir çalışma yürütmeye başlamıştır. Bu çerçevede GKRY'nin ilk hamlesi, Mart 2003'te kendi deniz yetki alanlarını belirleyip bunu ilan etmesi olmuştur. Bu adımla beraber diplomatik girişimleri yoğunlaştıran GKRY, yine aynı tarihte Mısır ile MEB sınırlarını belirleyen bir anlaşma imzalamıştır. GKRY' nin bu hamlelerini sırasıyla 2007 yılında Lübnan ve 2010 yılında İsrail ile yaptığı MEB anlaşmaları takip etmiştir (Darbouche vd., 2012, 8). GKRY, bu anlaşmalarla beraber Yunanistan'ın yanında Mısır ve İsrail ile ortak politikalar yürütmeye başlamıştır. Türkiye ise, GKRY'nin attığı bu adımları eleştirmenin yanı sıra anlaşmaların hiçbirinin Türkiye açısından bir geçerliliğinin olmadığını, uluslararası hukuka uygun düşmediğini ve bu anlaşmaları tanımadığını dile getirmiştir (Örnek \& Mızrak, 2016, 20). Ayrıca, bu anlaşmaları imzalayan Lübnan ve Mısır'a nota gönderilerek, Kıbrıs sorununun Türkiye açısından hassas bir mesele olduğu belirtilmiştir. GKRY ise Türkiye'nin tepkilerini görmezden gelerek belirlediği MEB sahaları doğrultusunda faaliyetlerini yoğunlaştırmış ve 2007 yılında Kıbrıs açıklarında 13 adet hidrokarbon arama sahası belirlemiştir (Yaycı, 2012, 17-18). GKRY, belirlediği bu sahalarda küresel enerji şirketlerine ruhsat vermek suretiyle arama çalışmalarına başlamıştır. Bu noktada bugüne kadar ExxonMobil, ENI, Total, Shell, Kogas, Delek gibi küresel enerji şirketleriyle anlaşan GKRY, Doğu Akdeniz enerji meselesinin uluslararası bir boyut almasına öncülük etmiştir (Özer, 2013, 76). Söz konusu enerji şirketleri aracılığıyla farklı noktalarda önemli keşifler yapılmış ve GKRY, birçok aktörün desteğini alarak bölgedeki çalışmalarını yoğunlaştırmıştır. GKRY'nin hidrokarbon arama faaliyetleri 
hususunda yetersiz olmasından dolayı küresel enerji şirketleriyle anlaşması ve meseleyi uluslararası bir boyuta taşımasındaki en önemli amaç, Türkiye ile yaşanan gerginliklere ve anlaşmazlıklara karşı enerji şirketleri aracılığıyla farklı ülkelerden destek almak ve Türkiye'nin muhtemel müdahalelerine engel olmaktır. Bu noktada GKRY'nin başarılı bir siyaset izlediği görülmektedir. Ancak yine de GKRY'nin bölgeyi 13 parçaya bölmesi ve küresel enerji şirketlerini bölgeye davet etmesi, Türkiye ve KKTC'nin tepkisini çekmiştir. Çünkü GKRY'nin belirlemiş olduğu 13 adet arama noktasının 5 adedi Türkiye'nin hak iddia ettiği sahalarla çakışmakta, kalan sahalarda ise KKTC'nin de hak ve çıkarları bulunmaktadır (Tiryakioğlu, 2019).

Doğu Akdeniz enerji kaynakları, GKRY için ekonomik kazanç sağlama noktasında oldukça önemlidir. Ada'nın enerji ihtiyacının düşük olması sebebiyle Kıbrıs açıklarında keşfi gerçekleşen kaynağın tamamına yakını ihraç edilebilecek niteliktedir. Bu sebeple keşfi gerçekleşen hidrokarbon kaynakları, GKRY açısından önemli bir zenginlik olarak görülmüştür. $A B$ için önemli bir enerji merkezi olma gayreti içerisinde olan GKRY, kaynakların Avrupa'ya nakli konusunda önemli adımlar atmış ve çeşitli ülkeler ile iş birliği yapmıştır. Bu adımlardan en önemlisi hiç şüphesiz $A B^{\prime}$ nin de desteklediği Doğu Akdeniz Doğal Gaz Boru Hattı Projesi (Eastern Mediterranean Natural Gas Pipeline, EastMed) olmuştur. Bu proje ile İsrail kaynaklarının GKRY üzerinden Yunanistan'a ve oradan da Avrupa'ya iletilmesi planlanmıştır. 2025 yılına kadar hayata geçirilmesi düşünülen projenin, GKRY üzerinden geçecek olması hem ülkenin önemli bir gelir elde etmesini sağlayacak hem de GKRY, $A B$ için önemli bir enerji üssü haline dönüşecektir. Ayrıca GKRY, bu proje ile hem finansal açıdan rahatlamayı hem de Türkiye'den gelebilecek tehditlere karşı $A B^{\prime}$ nin desteğini almayı planlamaktadır. Bu amaca ulaşmak için 2019 yılının Ocak ayında GKRY, Yunanistan, İtalya, Ürdün, Mısır ve İsrail bir araya gelerek yeni kaynak keşfi yapmak ve keşfi gerçekleşen kaynaklardan büyük ölçüde istifade etmek için Doğu Akdeniz Gaz Forumu'nu kurmuşlardır (Mitchell, 2020, 1). $\mathrm{Bu}$ ülkelere ek olarak Filistin, foruma sonradan dâhil olmuştur. 9 Mart 2021 'de ise Fransa foruma katılmıştır (Apim, 2021). Bu şekilde genişlemekte olan Forum ile Doğu Akdeniz bölgesinin en uzun kıyısına sahip olan Türkiye, kaynaklar üzerinde hak iddia etmesine rağmen yalnızlaştırılarak saf dışı bırakılmak istenmiştir (i̇stikbal \& Boyraz, 2019, 75). Tüm bunlara ek olarak askeri açıdan da Ingiltere, Fransa, Mısır ve İsrail'in desteğini alan GKRY, işbirliklerini askeri anlamda da artırmıştır. Dolayısıyla GKRY, günümüze dek hem Kıbrıs'ta tek egemen güç olmak maksadıyla hareket etme çabası içerisinde olmuş hem de Doğu Akdeniz kaynaklarına yönelik $A B$ başta olmak üzere farklı bölgesel ve küresel aktörlerin desteğini almıştır (Alptekin, 2015, 8).

\section{TÜRKIYE VE GKRY'NIN DOĞU AKDENIZ ENERJi POLITIKALARININ NEOREALIST PERSPEKTIFTEN DEĞERLENDIRILMESI}

Siyasi, etnik, ekonomik, hukuki çatışmaların çok yoğun yaşandığı Doğu Akdeniz' de, kıyıdaş aktörler daima teyakkuz halindedir ve tansiyon sürekli artış göstermektedir. Türkiye ve GKRY özelinde ele alındığında, iki aktör arasında tarihsel süreçte kronikleşen sorunlara enerji kaynaklarının tespit edilmesiyle yenileri eklenmiştir. Hem GKRY'nin hem de Türkiye'nin kendi ulusal çıkarları doğrultusunda hak sahibi olmak istediği bu kaynaklar, iki aktörün rekabet etmesine ve çıkarlarının çatışmasına sebep olmuştur. Bu bağlamda, çalışmanın bu bölümünde, Türkiye ve GKRY'nin hidrokarbon kaynaklarına yönelik izledikleri önceki bölümde ele alınan politikalar, neorealist teorinin ortaya koyduğu savlar ile bağdaştırılarak analiz edilmektedir. Neorealist teorinin özellikle öne çıkan ulusal çıkar, güç, çatışma, rekabet, anarşi, ittifak, iş birliği, güç dengesi, güvenlik gibi kavramları ile iki aktörün enerji kaynaklarına yönelik politikaları değerlendirilmektedir. Bu açıdan her bir kavrama ayrı ayrı vurgu yapılarak iki aktörün Doğu Akdeniz'e yönelik politikalarında neorealist teorinin izlerine ne ölçüde rastlandığı tartışımaktadır.

\section{1. "Ulusal Çıkar” Kavramı}

Neorealizm için önemli bir kavram olan ulusal çıkar, uluslararası ilişkilerde sıkça kullanılan bir kavramdır. Bu kavram, bir devletin uluslararası davranışını tanımlama, açıklama, tahmin etme ve anlama girişimlerinin merkezinde yer alır (Nincic, 1999, 29). Bu kapsamda geçmişten günümüze bütün devletler ve devleti yönetenler, eylemlerini ulusal çıkar adına yaparlar ve politikalarını bu kavram ile açıklarlar. Dolayısıyla günümüze kadar dünyada meydana gelen savaşlarda ve çatışmalarda ulusal çıkar kavramı, daima devletlerin gözettiği ve dikkate aldığı bir kavram olmuştur.

Neorealizme göre devletlerin ulusal güvenlik hedefi, ulusal çıkarları korumak ve gücü maksimize etmektir. Temel aktör olan devletler, güvenlik için çabalarken, rakip devletler karşısında güçlerini genişletmeye çalışırlar. Böylelikle bölgesel, ekonomik ve askeri güvenliğin sağlanması bir devletin ulusal çıkar hesabını oluşturur. Waltz'a $(1979,134)$ göre, bir aktörün kendi ulusal çıkarlarına göre hareket etmesi, güvenlik gereksinimlerini karşılamaya çalıştığı anlamına gelir. Aynı zamanda, bir devletin diğerlerine kıyasla sahip olduğu güç düzeyi, devletleri bu tür çıkarları gözetmeye zorlar. Bu kapsamda neorealizme göre devletler, kendi güvenliklerini muhafaza etmek ve güçlerini maksimize etmek için ulusal çıkarlarını dikkate alarak dış politikalarını 
belirler. Dolayısıyla neorealizme göre ulusal çıkar kavramı, devletlerin dış politikalarına yön veren bir kavramdır (Waltz, 1979, 134).

$\mathrm{Bu}$ çerçevede ele alındığında Türkiye ile GKRY'nin hidrokarbon kaynaklarına yönelik izledikleri politikalar, iki tarafın da kendi ulusal çıkarlarına hizmet etmektedir. Özellikle GKRY'nin, Türkiye'yi ve KKTC'yi izole etme ve yalnızlaştırma çabası, kaynaklardan tek başına faydalanmak istemesinin bir sonucudur. Diğer taraftan Türkiye hem kendisinin hem de KKTC'nin haklarını gözeterek GKRY'nin bu emellerini boşa çıkarma çabasındadır. Zira KKTC'nin haklarını gözetmek de Türkiye'nin ulusal çıkarlarına hizmet etmektedir. Dolayısıyla iki aktör açısından da son derece önemli getirileri olan hidrokarbon kaynakları üzerinde tarafların çıkarları çatışmaktadır. Bu kapsamda kaynaklardan maksimum fayda sağlamak için gayret gösteren iki aktörün de ulusal çıkarlarını dikkate alarak politika yürütmeleri rasyoneldir. Dolayısıyla neorealist teorinin vurgu yaptığı ulusal çıkar kavramı, Türkiye ve GKRY'nin Doğu Akdeniz enerji rezervlerine yönelik izledikleri politikalarında sıkça karşımıza çıkan bir kavram olmuştur.

\section{2. "Güç" Kavramı}

Neorealist teori açısından önemli olan ve Türkiye ile GKRY'nin enerji kaynaklarına yönelik politikalarında öne çıkan bir diğer kavram, güç kavramıdır. Neorealizme göre, devletler öncelikle güç ararlar ve menfaatlerini güç açısından tanımlarlar (Keohane, 1984, 164) ve anarşik uluslararası sistemin bir sonucu olarak güç için mücadele ederler (Brown \& Ainley, 2005, 92). Devletlerin üzerinde merkezi bir otorite yoktur. Bu durum, bir devletin başka bir devlet tarafından saldırıya uğramayacağının veya işga edilmeyeceğinin garantisinin olmadığı anlamına gelir ki bu da devletlerin kendilerini koruma arzusunu ve güvende hissetmek için güçlü olma ihtiyacını tetikler. Ayrıca neorealist teoriye göre güç, "bir amaca giden araçtır ve nihai amaç hayatta kalmaktır" (Mearsheimer, 2001, 78). Dolayısıyla sistemdeki her oyuncu hem bölgesel hem de uluslararası alanda hayatta kalmaya çalışmak zorundadır. $\mathrm{Bu}$ da devletleri güç elde etmeye zorlamaktadır ve Waltz $(1979,102)$, anarşik uluslararası sistemin kaçınılmaz olarak güç politikasına yol açtığını iddia etmektedir.

Neorealizmin ortaya koyduğu güç perspektifi Türkiye ve GKRY'nin enerji kaynaklarına yönelik politikalarında da karşımıza çıkmaktadır. İki aktör, mevcut uluslararası konjonktürde tehditleri ortadan kaldırmak, güvenliklerini sağlamak ve son tahlilde hayatta kalmak için hidrokarbon kaynaklarını araçsallaştırarak güçlerini maksimize etmek istemektedir. Zira enerji, ülkelerin güçlerini maksimize etmesi açısından son derece önemli bir kaynaktır (Zahid, 2008, 167). Doğu Akdeniz'de tespit edilen petrol ve doğal gaz, tarafların hem ekonomik gücünü artırıcı hem de dışa bağımlılıklarını azaltıcı niteliktedir. Bu sebeple Türkiye ve GKRY, kaynaklara erişmeyi, çıkarmayı, taşımayı ve tüm bu faaliyetlerin getirilerinden maksimum düzeyde yararlanmayı bir güç unsuru olarak görmektedir. Ancak iki tarafın da eşzamanlı ortaya koyduğu bu amaç, kaynakları elde etme rekabetini ve mücadelesini beraberinde getirmektedir. Dolayısıyla neorealizm açısından önemli olan güç kavramı, Türkiye ve GKRY'nin Doğu Akdeniz enerji politikalarında rasyonel bir fayda sağlama çabası ile karşııık bulmaktadır.

\section{3. "Çatışma" ve "Rekabet" Kavramları}

Türkiye ve GKRY'nin Doğu Akdeniz politikalarının neorealist perspektiften analizinde ele alınması gereken diğer kavramlar çatışma ve rekabet kavramlarıdır. Neorealizme göre, uluslararası sistem, bağlayıcı anlaşmalar yapıp uygulayabilecek egemen bir üst otoriteden yoksundur. Bu yüzden neorealistler, uluslar üstü bir otoritenin yokluğunun devletler arasındaki çatışmanın birincil nedeni olduğuna inanır (Waltz, 1979, 112). Dolayısıyla anarşik sistem, tüm çatışmaların kökenini oluşturur (Pechlivanis, 2012, 2). Bu çatışmalarla beraber uluslararası sistemde bir rekabet ortamı oluşur. Ayrıca neorealist teori açısından devletler, birbirlerini rakip olarak gördükleri için uluslararası sistem içerisinde çatışma ihtimali her zaman vardır. Bu sistem içerisinde devletlerin birbirlerine tam anlamıyla güvenemeyeceğini dile getiren teori, şüpheci veya kuşkucu bir yaklaşımı benimser. Yani devletler, her zaman birbirlerine şüphe duyar ve kendilerini olası bir çatışmaya hazırlar (Parent \& Rosato, 2015, 54).

Neorealizmin çatışma ve rekabet üzerine ortaya koyduğu bu görüşler, Türkiye ve GKRY arasındaki sorunları analiz etmede anlamlı bir perspektif sunmaktadır. Türkiye, diplomatik anlamda GKRY'yi bir devlet olarak tanımamasının yanı sıra GKRY'ye karşı her zaman şüphe duymuş ve politikalarını bu çerçevede belirlemiştir. Ayrıca tarafların enerji kaynakları üzerinde çatışma ve rekabet içerisinde olması da neorealist teorinin izlerini gösterir. İi aktör de, Kıbrıs çevresindeki kaynaklar üzerinde hak iddia ederken uzlaşmak ve paylaşmak yerine çatışma ve rekabete sürüklenmiştir. Buna ilaveten, Türkiye ve GKRY'nin çatışma halinde olmasının başlıca sebebi, yine neorealizm ile açıklanabilen ulusal çıkar ekseninde güç maksimize etme arzusudur. Enerji kaynaklarına hâkimiyet ile uluslararası sistem içerisinde daha etkili bir konuma kavuşmak isteyen iki aktör, bu amaca ulaşmak için çatışmayı ve rekabeti göze almıştır. Bu kapsamda askeri güçlerini ve deniz filolarını bölgede hazır bekleten Türkiye, yaptığı askeri tatbikatlar ile 
de olası bir çatışmaya her zaman hazır olduğunu göstermiştir. Aynı şekilde $A B D$ ve $A B$ ile askeri yakınlıklar kurmaya çalışan GKRY, Türkiye'yi caydıracak veya durduracak adımlar atarak rekabeti sürdürmüştür. Öte yandan, askeri olmayan önlemler de devreye sokulmakta örneğin $A B$ üyesi olan GKRY, veto gücünü somut olarak Türkiye aleyhine kullanmakta, Yunanistan ile ortak hareket etmekte ve $A B$ dayanışması argümanı ile Türkiye'nin $A B$ tam üyelik perspektifine de olumsuz etki yaratmaktadır (Uygun, 2021).

\section{4. "Güç Dengesi" Kavramı}

Türkiye ve GKRY'nin Doğu Akdeniz politikaları özelinde neorealist teorinin izlerini taşıyan bir diğer kavram ittifak kavramıdır. Bu kavram, iş birliği ve güç dengesi ile birlikte kullanılmakta, neorealizme göre, uluslararası sistem içerisinde ittifaklar ve iş birlikleri nadiren gerçekleşmektedir. Sistemin anarşik yapısından dolayı devletler daha çok çatışmaya meyillidir. Her devletin gelecekteki niyetlerinin ve eylemlerinin belirsizliği, iş birliğine aykırıdır (Grieco, 1988, 500). Ancak yine de aktörler, tehditlere ve zorluklara karşı, denge sağlamak amacıyla diğer aktörler ile ittifak ve iş birliği yapabilir. Aktörler kurdukları ittifaklar ile karşıt güçleri dengeleyerek tehditleri minimize etmeye çalışır. Bu kapsamda dengelenecek tehdit veya güç ne kadar büyükse, ittifakın bütünlüğü de o kadar büyük olur. Bu bağlamda, neorealizm, güç dengesizliklerine ve tehditlere yanıt olarak ittifakların kurulması gerektiğini açıkça savunur (Chun, $2000,75)$. Ortak bir rakibe karşı ittifak kurulması ve işbirliği tesis edilmesi gerekliliğine vurgu yapan neorealizme göre bu davranış, devletler açısından en rasyonel seçenektir. Zira neorealizm açısından devletlerin birincil gayesi, hayatta kalmaktır. Dolayısıyla kurulan ittifaklar ve ortaklıklar, devletlerin hayatta kalmak için gerektiği zaman atması gereken önemli adımların başında gelir. Bu kapsamda zayıf devletler genellikle gücü dengelemek için ittifak kurarken daha güçlü devletler hâlihazırdaki kapasitelerini artırmak için ittifaklar oluşturur. Bu çerçevede oluşturulan ittifaklar, genelde devletlerin rakiplerine karşı birbirlerine yardımcı olmasını ve çıkarlarını korumasını sağlar. Dolayısıyla neorealizme göre devletler, genelde ittifaklardan kaçar ancak her devletin zor durumlara ve tehditlere karşı bir ittifak politikası olmalıdır (Dar vd., 2017, 45). Bu çerçevede devletlerin zor zamanlarda kurduğu ittifaklar, güç dengesinin oluşmasını sağlar. Neorealizm açısından güç dengesi, otomatik olarak devletin kendi güvenliğini sağlama ve hayatta kalma eğilimi sonucu ortaya çıkar (Bordner, 1997).

Güç dengesi kavramı enerji alanında ele alındığında ise, devletler gücü içsel ve dışsal olmak üzere iki şekilde dengeler (Nexon, 2009, 341). Devletin yurtiçi enerji talebini kendi kaynaklarıyla karşılama fırsatı, bir devletin daha fazla ekonomik büyümesini artırması için bir teşvik yaratır. Bu çaba, içsel güç dengesini ortaya koyar. Aynı şekilde devletin enerji güvenliğini sağlamak için kapasitesini güçlendirmeye çalışması, yine içsel güç dengesini sağlama çabasıdır. Buna karşın devletin kendi kapasitesi ile çevresindeki kaynakların üretimini sağlayamayıp bölgesel ve küresel aktörler ile işbirlikleri yaparak bu kaynakları üretme ve işletme çabası içerisine girmesi ise dışsal güç dengesi olarak tanımlanabilir (Nexon, 2009, 341).

Türkiye ve GKRY'nin Doğu Akdeniz politikaları neorealist perspektiften incelendiğinde, iki aktörün de izlediği politikalar ve attıkları taktiksel adımlar rasyonel nitelik taşımaktadır. Özellikle GKRY'nin kendisinden daha güçlü gördüğü bir rakibi olan Türkiye karşısında bölgedeki diğer kıyıdaş devletler ve küresel aktörler ile yakın ilişkiler kurarak işbirliği yapması ve gücü dengeleme çabası göze çarpmaktadır. Bu tutum, GKRY için dışsal güç dengesini oluşturma çabasıdır. Bu kapsamda GKRY'nin işbirliği içerisinde olduğu aktör sayısı oldukça fazladır. Kıyıdaş devletlerden İsrail, Mısır ve Yunanistan ile ortak hareket eden GKRY, aynı şekilde $A B D$, Fransa, İtalya ve $A B$ gibi küresel aktörler ile de işbirliği yaparak büyük güçlerin desteğini alma gayretindedir. Ayrıca GKRY, yaptığı ittifaklar ile ulusal çıkarları kapsamında Doğu Akdeniz kaynaklarından maksimum düzeyde faydalanmak istemektedir. Bu çerçevede ortaya atılan EastMed projesi, GKRY'nin çıkarlarına hizmet eden ve ekonomik anlamda gücünü arttırıcı mahiyette bir projedir. GKRY, söz konusu projenin hayata geçmesi için ulusal çıkarlarının öngördüğü ölçüde bölgesel ve küresel aktörler ile işbirliği yapmaktadır.

Diğer taraftan GKRY'nin izlediği bu işbirliği ve ittifak politikalarına karşı Türkiye, kendi imkânlarıyla bölgedeki sondaj faaliyetlerini sürdürerek içsel güç dengesini sağlama gayreti içerisindedir. Bunun yanında Türkiye'nin Libya ile atmış olduğu adım, neorealist teorinin ittifak, işbirliği ve güç dengesi düşünceleri ile uyuşmaktadır. Zira Türkiye'nin bölgede Libya ile işbirliği yapması, ulusal çıkarlarını koruması açısından ve GKRY'nin kurduğu ittifakların karşısında bölgede yalnızlaşmamak için dengeyi sağlaması açısından önemlidir. Ayrıca Türkiye'nin KKTC ile yaptığı anlaşmadan sonra işbirliği adımlarını ilerleterek enerji kaynaklı yaşanabilecek tehdit ve tehlikeleri bertaraf etme çabası açısından neorealizmin ittifak ve işbirliğine yönelik görüşleri ile örtüşmektedir. Buna karşın, belirtilmelidir ki Türkiye'nin ikili antlaşma aracılığıyla işbirliği sağladığı KKTC ve Libya, uluslararası hukuk açısından hükümetlerinin meşruiyeti tartışmalı aktörlerdir. Öte yandan, Türkiye, ulusal çıkarlarına göre hareket ederek uzun süredir sorunlar yaşadığı İsrail ile enerji konusunda işbirliği yolları aramaktadır. Buna ek olarak Sisi yönetimindeki Mısır ile de görüşmelere açık 
olduğunu belirten Türkiye, ulusal çıkarlarının gerektirdiği ölçüde iş birliğine ve ittifaka her zaman hazır olduğunu ifade etmektedir. Dolayısıyla neorealizmin savunduğu şekliyle Türkiye ve GKRY, güçlerini artırmak, güç dengesini sağlamak ve kazançları maksimize etmek için bölgesel ve küresel aktörler ile iş birliği ve ittifak kapısını açık tutmaktadır (Çam, 2019).

\section{5. "Güvenlik" Kavramı}

Neorealist teori ışığında ele aldığımızda Türkiye ile GKRY'nin Doğu Akdeniz politikalarında karşımıza çıkan bir diğer kavram güvenlik kavramıdır. Neorealizme göre güvenlik, devletlerin hayatta kalmaları için göz önünde bulundurması gereken bir kavramdır. Uluslararası sistemin anarşik yapısından dolayı devletler daima güvenlik açığı hisseder. Dolayısıyla devletlerin temel gayesi, güvenlik tehditlerini ortadan kaldırmaktır. Bu çerçevede devletler, güç elde ederek tehditler karşısında güvenlik açıklarını minimize etmek ister. Ancak her devletin böyle bir politika benimsemesi bir güvenlik ikilemine (security dilemma) yol açar. Bir devlet rakibi karşısında güç elde ederek kendi güvenliğini artırmak isterken bunun sonucunda rakibinin tehdit algısı artar ve güvenliği azalır. Dolayısıyla devletler arasında güvenlik ikilemi daima devam eder (Beyer, 2018, 9-10).

Neorealizm için bir devletin kendi güvenliğini sağlayabilmesinin temel koşulu askeri kapasitesini artırmasıdır. Askeri anlamda güçlü olan bir devlet, gelebilecek tehditleri caydırma yeteneğine sahip olacağı için askeri açıdan yeterli olmak bir devletin güvenliğinin öncelikli koşuludur. Bu anlamda neorealizm, güvenlik konusundaki analizlerinde askeri alana daha fazla ağırlık vermiştir. Çünkü devletler, rakiplerinin kendisi hakkındaki fikirlerini bilemez ve bu bilinmezlik güvenlik tehdidinin ana kaynağıdır. Bu sebeple neorealizm açısından devletler, askeri kapasitelerini artırarak en azından mevcut tehditlere karşı hazırlıklı olmalıdır. Bu nedenlerle neorealizme göre güvenliği sağlamak için öncelikli şart, güçlü bir orduya sahip olmaktadır (Clempson, 2011, 1).

Diğer taraftan, neorealizmin güvenlik algısı daha çok askeri odaklı olsa da küreselleşmenin ardından devletlerin ekonomik anlamda birbirlerini etkilemeye başlaması, askeri alanların dışında da bir güvenlik açığı oluşmasına sebep olmuştur. Örneğin, enerji güvenliği, günümüz dünyasında giderek daha önemli bir hale gelmiştir. Zira enerji olmadan bir devletin ekonomisi durma noktasına gelir ve devlet, orduyu yönetemeyecek duruma düşebilir (Metcalf, 2014, 156). Dolayısıyla günümüz dünyasında enerji talepleri artmaya devam ettikçe, devletler artık enerjiyi sert bir diplomasi yöntemi olarak kullanmaya başlamıştır (Cesnekas, 2010, 41). Neorealizm açısından devletin en önemli hedefi hayatta kalmak ve tehditleri azaltmak olduğundan, günümüz şartlarında enerji güvenliğinin sağlanması da devletlerin bu hedefine hizmet eden başlıca unsurlardan bir tanesi haline gelmiştir. Dolayısıyla devletler için stratejik anlamda bir ulusal çıkar haline gelen enerji kaynaklarına sahip olmak ve sahip olunan kaynakların güvenliğini sağlamak, devletlerin birbirleriyle olan rekabetlerinde üstünlük kazanmalarını kolaylaştırır (Jaybhay, 2020). Bu açıdan enerji güvenliği önem teşkil etmektedir.

Enerji güvenliği kavramı, BM tarafından "enerjinin çeşitli biçimlerde, yeterli miktarlarda ve uygun fiyatlarla sürekli mevcudiyeti" olarak tanımlanmıştır (Sudarshan \& Noronha, 2009 , 5). Aynı zamanda bu kavram, enerji kaynaklarına erişimin güvence altına alınması anlamında da kullanılmaktadır. Enerji güvenliği, bir küresel güvenlik meselesidir ve bu nedenle her devletin ulusal güvenliğini ilgilendirmektedir (Kalambura vd., 2014, 229). Mevcut uluslararası sistem içerisinde devletlerin enerji kaynaklarını güvence altına alması, devletin kendi güvenliğini sağlaması açısından önem arz etmektedir.

Enerji güvenliğini, ekonomik güç alanı içerisinde ele almak mümkündür. Çünkü sahip olunan enerjinin güvenliğini sağlamak, bir devletin kendi gücünü artırmanın yanı sıra ekonomik bir kazanç sağlayacaktır. Dolayısıyla enerjiye sahip olan devlet, ekonomik anlamda diğer devletlerden daha üstün bir seviyeye ulaşabilecek ve uluslararası alandaki nüfuzunu artırabilecektir. Yani enerji kaynakları, devletlerin gücünü artırıcı bir potansiyele sahiptir zira bir devlet ne kadar çok enerji kaynağına sahip olursa o kadar çok güce ulaşır (Cesnekas, 2010, 38). Dolayısıyla devletler, sahip oldukları enerji kaynaklarının güvenliğini sağlayarak aslında kendi güç ve çıkarlarını korumaktadır. Bu açıdan enerji güvenliği kavramı, devletlerin ulusal çıkarlarına hizmet etmektedir. Bu sayede neorealizm açısından birincil unsur kabul edilen devletlerin hayatta kalma hedefi, enerji güvenliğinin sağlanmasıyla daha da kolaylaşmaktadır (Solc, 2013, 82).

Türkiye açısından düşünüldüğünde, Doğu Akdeniz'de enerji kaynaklarında hâkim aktör olmak, ülkenin güvenliğini artırıcı niteliktedir. Zira Türkiye' nin, enerji kaynağı ihtiyacının büyük bir bölümünü farklı ülkelerden karşılaması enerji konusunda dışa bağımlı olduğunu göstermektedir ve bir güvenlik açığı oluşturmaktadır. Türkiye'nin bu kaynakları dışarıdan temin etmesi, tedarikçi ülkelere Türkiye'ye karşı bir üstünlük kazandırmaktadır. Dolayısıyla Türkiye, rakipleri karşısında daha güvensiz bir duruma düşmektedir. Bu açıdan Doğu Akdeniz kaynakları, Türkiye'nin güvenliğini artırıcı bir etkiye sahiptir. Enerji kaynaklarının ülkelerin askeri ve ekonomik 
gücünü artırıcı yönü düşünüldüğünde Türkiye, Doğu Akdeniz kaynakları üzerindeki haklarını ve çıkarlarını koruyarak gücünü ve güvenliğini artırmak istemektedir. Bu açıdan Türkiye, bu kaynakları kullanarak kendisine yönelik tehditleri minimize etmenin peşindedir. Bu çerçevede bölgedeki kaynaklar, Türkiye'nin diğer devletler karşısında rekabet etmesini kolaylaştırmakta ve ülkenin ulusal çıkarlarına büyük ölçüde fayda sağlamaktadır. Bu sebeple Türkiye, güvenliğini artırıcı bir etkiye sahip olan kaynaklara yönelik ulusal çıkarlarına hizmet eden nitelikte aktif politikalar izlemelidir. Özellikle 2020 yılından itibaren Doğu Akdeniz'de artan gerginlik Türkiye'nin böyle bir yaklaşım ile GKRY, Yunanistan ve $A B$ gibi aktörlerin 'illegal' ve 'agresif' olarak nitelendirdiği bir tutum sergilemesine yol açmıştır (Uygun, 2021). Her ne kadar bölgede sorunlu alanlardaki sondaj faaliyetlerini durdurmuş olsa da, son yıllarda izlediği politikalar ve diplomatik girişimler Türkiye'nin enerji kaynakları üzerinde hâkimiyet kurarak güvenlik açıklarını minimize etmek istemesinin bir göstergesidir.

Aynı şekilde GKRY de bölgedeki kaynaklar üzerinde hakimiyet kurarak bahsi geçen kazanımlara ulaşmak istemektedir. Özellikle Türkiye'ye karşı enerji güvenliğini sağlamak için bölgesel ve küresel aktörler ile işbirliği yapması ve ittifaklar kurması, GKRY'nin gücünü ve güvenliğini artırmak istediğini göstermektedir. Ayrıca ada etrafındaki kaynaklar üzerinde Türkiye'nin ve KKTC'nin haklarını görmezden gelmesi ve bu sahalarda tek taraflı olarak sisimik faaliyetler yürütmesi, GKRY'nin de Türkiye gibi istekli ve kararlı olduğunu ortaya koymaktadır. Bu sebeple Türkiye ve GKRY, kaynaklar üzerinde rekabet ederek güçlerini ve güvenliklerini artırmanın peşindedir. İki aktör arasında enerji rezervleri ekseninde süregelen ihtilaflar iki aktörün güvenlik tehdit algılarını arttırmakta ve Doğu Akdeniz'de istikrarsızlığı körüklemektedir.

\section{SONUÇ ve DEĞERLENDIRME}

Doğu Akdeniz, tarih boyunca huzurun, barışın ve istikrarın arandığı bir coğrafya olagelmiştir. Günümüzde, kıyıdaş devletler arasındaki kronik sorunlar, bölgenin düzeninin ve istikrarının önündeki en önemli engeldir. Özellikle Kıbrıs adasına yönelik 1950'li yıllardan günümüze kadar uzanan sorun, Doğu Akdeniz açısından huzuru ve barışı engeller niteliktedir. Türkiye, GKRY'yi diplomatik anlamda tanımamakta GKRY ise, Türkiye ve KKTC karşıtı eylemler ile adanın tamamına sahip olmak ve uluslararası arenada tek egemen temsilci olmak için mücadele etmektedir. Taraflar arasında böyle bir problem mevcutken Akdeniz'in doğusunda keşfedilen geniş hidrokarbon rezervleri, Türkiye ve GKRY'nin anlaşmazlığının ve uyuşmazlığının denizlere taşmasına sebep olmuştur. Iki aktör, tespit edilen kaynaklara erişmek ve enerji rezervlerinden kendi ulusal çıkarları doğrultusunda istifade etmek için bu defa denizlerde karşı karşıya gelmektedir. GKRY'nin ada etrafında keşfedilen kaynaklara yönelik benimsediği politikalar, Kıbrıs adasının statüsüne yönelik izlediği stratejiler ile paralellik göstermektedir. Zira GKRY, adanın tek egemen temsilcisi iddiası ile enerji kaynakları üzerinde tek başına inisiyatif kullanmak isterken, bu durum, adanın diğer paydaşı olan KKTC'nin ve onun üzerinde garantörlük sıfatı olan Türkiye'nin kaynaklar üzerindeki haklarının ve çıkarlarının gasp edilmesi anlamına gelmektedir. Dolayısıyla Türkiye, GKRY'nin bu politikalarına karşı, KKTC'nin ve Türkiye'nin hakkını gözetmek maksadıyla son dönemde bölgede daha dinamik bir politika yürütme gayreti içinde olmuştur. Bu çerçevede Türkiye ve GKRY, zaten var olan ve uzun yıllar çözüme kavuşturulamayan Kıbrıs meselesine ek olarak yeni sorunlarla karşı karşıya kalmıştır. Doğu Akdeniz enerji kaynakları, Türkiye ve GKRY için yeni çatışma ve rekabet alanları doğurmuştur.

Nihayetinde, Türkiye ve GKRY'nin Doğu Akdeniz enerji kaynakları üzerinde çıkarlarının çatıştığı, iki aktörün rekabet halinde olduğu ve kaynakları ele geçirerek güç ve güvenliklerini maksimize etmek istedikleri görülmektedir. Dolayısıyla iki aktörün enerji kaynaklarına yönelik politikalarında uluslararası ilişkilerin devletler arasındaki çatışmayı konu edinen teorilerinden neorealist yaklaşımın izlerine rastlanmaktadır. Neorealist teoriye göre, sistemin anarşik yapısı, devletleri çatışmaya zorlar. Bu anlamda çatışma ve rekabet kaçınılmaz hale gelir. Devletler de bu çatışma ve rekabet durumuna karşı hayatta kalma mücadelesi verir. Neorealist teoriye göre hayatta kalmanın ve var olmanın temel aracı güçtür. Devletler, ancak güçlerini ve güvenliklerini artırarak, sistemde var olabilir. Bu açıdan Türkiye ve GKRY de enerji kaynaklarına hâkim olarak güç ve güvenlik düzeylerini artırıcı bir politika izlemektedir.

Neorealizmin önem atfettiği ulusal çıkar, güç, rekabet, çatışma, iş birliği, ittifak, güç dengesi ve güvenlik kavramları, Türkiye ve GKRY'nin Doğu Akdeniz enerji politikalarında sık sık karşımıza çıkmaktadır. Bu anlamda iki aktörün enerji kaynaklarına yönelik politikalarında neorealist düşüncenin etkisi yoğun bir şekilde hissedilmekte, aktörlerin rasyonel davrandığı görülmektedir.

Bu çalışmada, neorealist kuramın Kıbrıs çevresinde keşfedilen enerji kaynaklarına yönelik Türkiye ve GKRY'nin çatışmacı ve rekabetçi politikalarını analiz etmede ne derece etkin bir teorik çerçeve ortaya koyduğu analiz edilmiş ve iki aktörün politikalarında neorealist kuramın savlarına sıklıkla rastlandığı sonucuna varılmıştır. Bu çerçevede iki aktörün izlediği çatışmacı ve rekabetçi politikalar neticesinde Kıbrıs meselesine ek olarak Doğu Akdeniz enerji kaynaklarının paylaşımı ve Avrupa topraklarına taşınması sorunları ortaya çıkmış ve bu durum bölgenin tansiyonunu artırıcı bir etki 
yaratmıştır. Tarafların tutumlarında kararlı olduğu ve geri adım atmadığı dönemlerde, bölgede kriz derinleşmektedir. Dolayısıyla kaynakların kıyıdaş aktörlerce etkin bir şekilde kullanılmasını sağlayacak olan adım, uluslararası hukuk gözetilerek işbirliği yapılmasıdır. Bu yönde atılacak bir adım bölgedeki gerilimi azaltabilir ancak yapılan analiz neticesinde, Türkiye ile GKRY arasında böyle bir adımın yakın gelecekte atılması ihtimal dâhilinde görülmemektedir.

\section{KAYNAKÇA}

Acer, Y. (2019). Doğu Akdeniz'de deniz yetki alanları ve Türkiye-Libya Mutabakatı. SETA Analiz, (301), 1-15.

Acer, Y. (2020). Perspektif: Türkiye-Libya deniz sınırı antlaşmasının Birleşmiş Milletler tarafından tescilinin önemi. SETA https://www.setav.org/perspektif-turkiye-libyadeniz-siniri-antlasmasinin-birlesmis-milletlertarafindan-tescilinin-onemi/.

Acer, Y. (2020). Doğu Akdeniz'de Yunanistan-Mısır deniz sınırı antlaşması ve Türkiye. Adalet Dergisi, 2(65), 13-26.

Ahmed, J. (2020). The theoretical significance of foreign policy in international relations- an analyses. Journal Of Critical Reviews, 7(2), 787-792.

Ak, G. (2013). Kıbrıs adası ve çevresindeki deniz dibi hidrokarbon zenginliklerinin adadaki sorunun çözümüne muhtemel etkileri. Motif Akademi Halkbilimi Dergisi Kıbrıs Özel Sayısı, 333-338.

Alptekin, G. (2015). Doğu Akdeniz enerji keşiflerinden sonra Akdeniz uyum firsatı ve bölge devletlerinin politikaları (2009-2015). 1-32.

Ametbek, D. (2019). Rusya'nın Doğu Akdeniz'deki tutumu. ANKASAM, https://www.ankasam.org/rusyanindogu-akdenizdeki-tutumu/.

Apim, E. (2021). France joins the Eastern Mediterranean Gas Forum. Econostrum, https://en.econostrum.info/France-joins-theEastern-Mediterranean-Gas-Forum_a921.html.

Arı, T. (2004). Uluslararası Illişkiler Teorileri. İstanbul: Alfa basım yayım.

Ashley, R. K. (1984). The poverty of neorealism. International Organization, 38(2), 225-286.

Bayeh, E. (2014). Theories on the role of international organizations in maintaining peace and security. International Journal of Multidisciplinary Research And Development, 1(7), 347-350.
Beyer, A. C. (2018). Abolishing the security dilemma: why we need to integrate the militaries. Cambridge Journal Of Eurasian Studies, 1-20.

Bordner, B. (1997). Rethinking neorealist theory: order within anarchy. http://brucebordner.com/Neorealism.html.

Boyraz, H. M., \& Balcı, O. (2021). Yunanistan ile GKRY'nin Doğu Akdeniz'deki hesapları başarısızlığa mahkum. Anadolu https://www.aa.com.tr/tr/analiz/yunanistan-ilegkry-nin-dogu-akdenizdeki-hesaplari-basarisizligamahkum/2183953.

Brown, C., \& Ainley, K. (2005). Understanding International Relations. New York, USA: Palgrave.

Caşın, M. H. (2019). Türkiye-Libya anlaşmasının hukuki ve stratejik boyutları. Anadolu Ajansı, https://www.aa.com.tr/tr/analiz/turkiye-libyaanlasmasinin-hukuki-ve-stratejik-boyutlari/1668270.

Cesnekas, G. (2010). Energy resources in foreign policy: a theoretical approach. Baltic Journal Of Law \& Politics, $3(1), 30-52$

Chun, C-S. (2000). Theoretical approaches to alliance: Implications on the R.O.K.-U.S. alliance". Journal of International And Area Studies, 7(2), 71-88.

Clempson, R. (2011). Are security Issues most effectively addressed by a neo-realist IR approach?. EInternational Relations, 1-4.

Cumhurbaşkanı Erdoğan: Biz Nasıl kimsenin toprağına göz dikmiyorsak, bize ait olanlardan da taviz vermeyeceğiz. (2020). Anadolu Ajansı, https://www.aa.com.tr/tr/turkiye/cumhurbaskanierdogan-biz-nasil-kimsenin-topragina-gozdikmiyorsak-bize-ait-olanlardan-da-tavizvermeyecegiz/1953549.

Çam, T. (2019). Türkiye-Libya Anlaşması Türkiye'nin Doğu Akdeniz politikasında önemli kazanım. Anadolu Ajansı, https://www.aa.com.tr/tr/dunya/turkiyelibya-anlasmasi-turkiyenin-dogu-akdenizpolitikasinda-onemli-kazanim/1662097.

Dar, A. I. vd. (2017). Alliances In International politics: a comparative study of Kenneth Waltz's and Stephen Walt's theories of alliances. Kaav International Journal Of Arts, Humanities \& Social Sciences, 4(3), 44-51. 
Darbouche, H. vd., (2012). East mediterranean gas: what kind of a game-changer?. The Oxford Institute For Enegy Studies, 1-33.

Delanoe, I. (2013). Cyprus, A Russian Foothold In The Changing Eastern Mediterranean. Middle East Review Of International Affairs, 17(2), 84-93.

Deutsche Welle (2021). İtalyan Şirketi Eni'den Kıbrıslı Rumlara Güvence. https://www.dw.com/tr/itayan$\%$ C5\%9Firketi-enidenk\%C4\%B1br\%C4\%B1sl\%C4\%B1-rumlarag\%C3\%BCvence/a-42998699.

Dışişleri Bakanlığı (2010). İsrail ile GKRY arasında imzalanan meb anlaşması hk. no: 288. https://www.mfa.gov.tr/no_-288_-21aralik-2010_israil-ile-gkry-arasinda-imzalanan-meb-anlasmasihk_.tr.mfa.

Dunne, T., Kurki, M., \& Smith, S. (2013). International relations theories discipline and diversity third edition. Oxford, United Kingdom: Oxford University Press.

Glaser, C. L. (1994). Realists as optimists: cooperation as self-help". International Security, 19(3), 50-90.

Grieco, J. M. (1988). Anarchy and the limits of cooperation: a realist critique of the newest liberal Institutionalism. International Organization, 42(3), 485-507.

Grigoriadis, I. N. (2014). Energy discoveries in the Eastern Mediterranean: Conflict or cooperation? Middle East Policy, 21(3), 124-133.

Gürsoy, B. (2005). Soğuk savaştan günümüze asimetrik tehdit. Ankara: IQ kültür sanat yayıncılık.

Güven, A. (2019). Güvenlik bağlamında saldırgan realizm ve savunmacl realizm. Illim ve Medeniyet, https://www.ilimvemedeniyet.com/guvenlikbaglaminda-saldirgan-realizm-ve-savunmacirealizm.html.

İstikbal, D., \& Boyraz, H. M. (2019). Doğu Akdeniz enerji kaynaklarına ekonomi-politik bir yaklaşım. Kıbrıs Araştırmaları ve incelemeleri Dergisi, 3(5), 69-86.

Jaybhay, R. (2020). A neo-realist theoretical perspective in energy security. The Kootneti, https://thekootneeti.in/2020/04/13/neo-realistperspective-energy-security/.

Jervis, R. (1978). Cooperation under the security dilemma. World Politics, 30(2), 167-214.
Kalambura, S. vd. (2014). Energy security and renewable sources of energy". Coll. Antropol, 38(1), 229-236.

Karagiannis, E. (2016). Shifting Eastern Mediterranean Alliances. Middle East Quarterly, 23(2), 1-11.

Karagöl, E. T. vd. (2016). Türkiye'nin enerjide merkez ülke olma arayışı. SETA, http://file.setav.org/Files/Pdf/20160420121430_tur kiyenin-enerjide-merkez-ulke-olma-arayisi-pdf.pdf.

Karagül, S. (2021). Doğu Akdeniz'de enerji eksenli ittifak girişimleri ve Türkiye. TYB Akademi, 11(31), 48-68.

Karakasis, V. P. (2014). The energy security question in the Eastern Mediterranean: Understanding the recent tensions (Part 1). Project Lead on the Cyprus Issue Project at Bridging Europe Paper No: 7, https://scholarlypublications.universiteitleiden.nl/ac cess/item\%3A2857007/view.

Kavaz, í. (2020). Doğu Akdeniz'deki enerji rekabeti üzerine bir değerlendirme. TYB Akademi, 11(31), 26-47.

Kedikli, U., \& Deniz, T. (2015). Enerji kaynakları mücadelesinde Doğu Akdeniz havzası ve deniz yetki alanları uyuşmazlığı. Alternatif Politika, 7(3), 399-424.

Keohane, R. (1984). After Hegemony: Cooperation and discord in the world political economy. New Jersey, USA: Princeton University Press.

Kısacık, S., \& Erenel, F. (2019). Doğu Akdeniz güvenlik algılamaları bağlamında, kalıcı yapılandırılmış işbirliği savunma anlaşması (The permanent structured cooperatıon- pesco) ve enerji güvenliği meselelerinin Avrupa Birliği-Türkiye ilişkilerine olası yansımalarını anlamak. Türkiye Siyaset Bilimi Dergisi, 2(1), 51-76.

Kökyay, F. (2020). Neorealizm Kuramı ve Türkiye'nin Doğu Akdeniz Enerji Politikası. Itobiad: Journal of the Human \& Social Science Researches, 9(3).

Lobell, S. E. (2010). Structural realism/offensive and defensive realism. Oxford Research Encyclopedia of International Studies, 1-23.

Mastanduno, M. (1997). Preserving the unipolar moment: Realist theories and U.S. grand strategy after the Cold War. International Security, 21(4), 49-88.

Mearsheimer, J. J. (2001). The tragedy of great power politics. New York: USA: W.W Norton Company.

Mearsheimer, J. J. (2009). Reckless states and realism. International Relations, 23(2), 241-253. 
Metcalf, G. E. (2014). The economics of energy security. The Annual Review Of Resource Economics, 6, 155174.

Mitchell, G. (2020). The Eastern Mediterranean Gas Forum: Cooperation in the shadow of competition. The Israeli institute For Regional Foreign Policies, 112.

Nexon, D. H. (2009). The Balance of Power in the Balance. Cambridge University Press, 61(2), s.330-359.

Nincic, M. (1999). The national interest and its interpretation. Cambridge University Press, 61(1), 29-55.

Orhun, F. Ç. (2017). Doğu Akdeniz enerji kaynaklarının Kıbrıs sorununa muhtemel etkileri. Vakanüvis Uluslararası Tarih Araştırmaları Dergisi, 2(2), 36-54.

Örnek, S., \& Mızrak, B. (2016). Bir güvenlik sorunu olarak Kıbrıs'ın enerji kaynakları ve uluslararası aktörlerin politikaları. Bilge Strateji, 8(15), 13-32.

Örselli, E., \& Babahanoğlu, V. (2019). Doğu Akdeniz'de açılmaya çalışılan pandoranın kutusu: Enerji kaynaklarından alan hâkimiyetine uzanan ekonomi politik hesaplar. Uluslararası Sosyal Araştırmalar Dergisi, 12(66), 388-400.

Özekin, M. K. (2020). Doğu Akdeniz'de değişen enerji jeopolitiği ve Türkiye. Güvenlik Stratejileri, 16(33), 151.

Özer, S. (2013). Doğu Akdeniz'de enerji güvenliği ve savaşları. Ortadoğu Analiz, 5(60), 68-79.

Pashakhanlou, A. H. (2018). The Past, Present and Future of Realism. E-International Relations,1-9.

Parent, J. M., \& Rosato, S. (2015). Balancing in neorealism. International Security, 40(2), 51-86.

Pechlivanis, P. (2012). Anarchy and war: a critique of Waltz's third image. E-International Relations, 1-5.

Pekcan, C., \& Uygun, A. G. (2021). Çin'in Akdeniz politikaları kapsamında Avrupa Birliği-Çin stratejik ortaklığı. Atatürk Üniversitesi iktisadi ve Idari Bilimler Dergisi, 35(3), 1145-1164.

Resmi Gazete (2019). Türkiye Cumhuriyeti hükûmeti ile Libya devleti ulusal mutabakat hükûmeti arasında Akdeniz'de deniz yetki alanlarının sınırlandırılmasına ilişkin mutabakat muhtırasının onaylanmasının uygun bulunduğuna dair kanun. https://www.resmigazete.gov.tr/eskiler/2019/12/2 0191207-2.htm.
Rose, G. (1998). Neoclassical realism and theories of foreign policy. World Politics, 51(1), 144-172.

Sandıklı, A., \& Kaya, E. (2012). Uluslararası ilişkiler teorileri ve barış. A. Sandıklı (ed.). Teoriler ışığında güvenlik, savaş, barış ve çatışma çözümleri, (ss. 133-164). İstanbul: Bilgesam Yayınları.

Snyder, J. (1991). Myths of empire: domestic politics and International ambition. New York, USA: Cornell university press.

Solc, M. (2013). Energy security - an important aspect of national security. Univerzita Obrany $v$ Brně, https://www.unob.cz/eam/Documents/Archiv/EaM _1_2013/\%C5\%A0olc.pd.

Sudarshan, A., \& Noronha, L. (2009). Contextualizing India's energy security. L. Noronha ve A. Sudarshan (ed.). India's energy security, (ss. 3-18). London, New York: Routledge.

Şahin, i. (2019). Energy conflıct and cooperatıon in the eastern medıterranean. Ortadoğu Araştırmaları Merkezi.

Temizer, M. (2020). Türkiye'nin denizlerdeki enerji filosu. Anadolu

Ajansı, https://www.aa.com.tr/tr/ekonomi/turkiyenindenizlerdeki-enerji-filosu/1949802.

Tiryakioğlu, M. B. (2019). Doğu Akdeniz'de enerji denklemi 1. Anadolu Ajansı, 9 Mayıs 2019, https://www.aa.com.tr/tr/analiz/dogu-akdenizdeenerji-denklemi-1/1474137.

TPAO (2019). Ham petrol ve doğal gaz sektör raporu. https://www.tpao.gov.tr/file/2005/2019-tpaosektor-raporu-3185ed3b4af5442c.pdf.

Turkey says to hold military drills in eastern Mediterranean. (2020). Reuters,

https://www.reuters.com/article/turkeygreece/turkey-says-to-hold-military-drills-in-easternmediterranean-idUKL8N2FT2P6.

Tüysüzoğlu, G. (2013). Savunmacı realizm ve saldırgan realizm bağlamında Karadeniz Havzası'ndaki çatışma gerçekliğinin değerlendirilmesi". Avrasya Etüdleri, 44(2), 57-85.

USGS (2010). Assessment of undiscovered oil and gas resources of the levant basin province, eastern mediterranean. U.S. department of the interior, https://pubs.usgs.gov/fs/2010/3014/pdf/FS103014.pdf. 
Uygun, A. G. (2021). Doğu Akdeniz'de Paylaşım Rekabeti: Türkiye-Yunanistan Gerginliği ve Avrupa Birliği'nin Tutumu. TYB Akademi, 11 (31), s. 69-89.

Waltz, K. N. (1979). Theory of International politics. Reading, Mass: Addison-Wesley Publishing Company.

Waltz, K. N. (1990). Realist thought and neorealist theory. Journal Of International Affairs, 44(1), 21-37.

Waltz, K. N. (2008). Realism and International Politics. London, United Kingdom: Routledge.

Wivel, A. (2011). Security dilemma. https://www.researchgate.net/profile/Anders-

Wivel-

2/publication/320211391_Security_dilemma/links/ 59d4e777a6fdcc181adc5d66/Securitydilemma.pdf.

Yaycı, C. (2012). Doğu Akdeniz'de deniz yetki alanlarının paylaşılması sorunu ve Türkiye". Bilge strateji, 4(6), 1-70.
Yazar, Y. (2011). Enerji ilişkileri bağlamında Türkiye ve Orta Asya ülkeleri. Hoca Ahmet Yesevi Uluslararası Türk Kazak

Üniversitesi, http://www.ayu.edu.tr/static/kitaplar/enerji_raporu .pdf.

Yıldız, D. (2008). Tarihi geçmişi, stratejik önemi ve su sorunu açısından Akdeniz'in doğusu. İstanbul: Bizim Kitaplar Yayınevi.

Yılmaz, A. (2012). Küresel dünyada uluslararası ilişkiler teoritemel kavramlar-yeni gelişmeler. Ankara: Kadim Yayınları.

Yunanistan'ın Libya'ya baskısı sürüyor. (2019). TRT Haber, https://www.trthaber.com/haber/dunya/yunanistan in-libyaya-baskisi-suruyor-444731.html.

Zahid, A. (2008). Energy-Gdp relationship: a causal analysis for the five countries of South Asia". Applied Econometrics And International Development, 8(1), 167-180. 